Nath, D., Reja, V.K. and Varghese, K., 2021. A framework to measure collaboration in a construction project. In: Sandanayake, Y.G., Gunatilake, S. and Waidyasekara, A. (eds). Proceedings of the $9^{\text {th }}$ World Construction Symposium, 9-10 July 2021, Sri Lanka. [Online]. pp. 2-13. DOI:XXX. Available from: https://ciobwcs.com/papers/

\title{
A FRAMEWORK TO MEASURE COLLABORATION IN A CONSTRUCTION PROJECT
}

\author{
Deepjyoti Nath ${ }^{1}$, Varun Kumar Reja ${ }^{2}$, and Koshy Varghese ${ }^{3}$
}

\begin{abstract}
Collaboration amongst stakeholders in a construction project plays a significant role in managing and completing a project successfully. It specifically helps in interface management amongst the stakeholders. Among the various aspects of collaboration, there are two key factors that predominant. Firstly, the psychological factors that define a person as a natural collaborator, and secondly, the project-level enablers that determine a collaborative project. Therefore, in this study, two inductive theories are developed- one for psychological factors and another for project-level enablers of collaboration. This study aims to identify the key psychological factors and project enablers associated with collaboration and develop a conceptual framework to measure collaboration in a construction project. The workflow of the conceptual framework is developed in the first part of the research, and the input requirements are quantified. Robust hypothesis testing methodology is adopted to identify the key psychological factors and project enablers. Hypotheses testing yields three specific psychological factors for defining a person as a natural collaborator, and six enablers are essential for facilitating project collaboration. These results are used as input parameters in the derived conceptual framework to measure the level of collaboration in a construction project.
\end{abstract}

Keywords: Collaboration in construction; Enablers of collaboration; Measuring collaboration; Psychological factors; Stakeholder management.

\section{INTRODUCTION}

Construction activities are unique in terms of trade flow. It requires several stakeholders to come together to deliver a specific service or product. The successful completion of construction projects depends on stakeholder management based on the size and complexity of construction projects. The interface management of the stakeholder is significantly impacted by the level of coordination amongst the involving stakeholders (Wang, 2000). The cited reasons for the lack of coordination are ineffective communication, poor collaboration, unbalanced risk allocation, etc. (Narayanan et al., 2019).

Moreover, for an economy like India, collaboration in construction projects is crucial as it addresses some of the inherent and common issues with project management. However, quantifying the extent of collaboration in a construction project can be a proper

\footnotetext{
${ }^{1}$ Department of Civil Engineering, IIT Madras, India, deepjyotinath96@gmail.com

${ }^{2}$ Department of Civil Engineering, IIT Madras, India \& UTS, Australia, varunreja7@gmail.com

${ }^{3}$ Department of Civil Engineering, IIT Madras, India, koshy@iitm.ac.in
} 
perspective of collaboration, as it will unveil critical concepts of collaborative working within construction projects. Additionally, limited research has been conducted on measuring collaboration in the Indian construction industry.

Therefore, this paper attempts to:

- Identify the key psychological factors and project level enablers associated with collaboration in the construction industry, and

- Derive a conceptual framework to measure the level of collaboration in a construction project.

To fulfill the objectives, a detailed methodology was proposed and is presented in Figure 1. Data collection included a questionnaire survey performed with Indian construction professionals. Appropriate hypothesis testing methodology was adopted to analyze the collected data in the questionnaire survey. The scope of this study is limited to the following stakeholders of a construction project: clients, project management consultants, designers, main contractors, and subcontractors. However, the study can be extended to any number of stakeholders as per the use case by following the same methodology.

This paper is divided into six sections. In the first section, the research problem is introduced, and the objectives for this study are presented. Section two presents the review of existing literature on construction collaboration. The result of the keyword search is also presented in this section. Section three presents the methodology adopted for the present study. The inductive theories (i.e., hypotheses H1 and H2) are also presented in this section. Section four presents the results of hypothesis testing and introduces the conceptual framework to measure collaboration. Discussion on the findings of the hypotheses testing and potential future work are presented in section five. Finally, section six concludes the study by showing the contribution of this research to the field of construction collaboration.

\section{LITERATURE REVIEW}

Among the several challenges of managing construction projects, interface management has always been a concern. Hence, the success of construction projects can be attributed to stakeholder management ( $\mathrm{Wu}$ et al., 2008). On the other hand, the client expects quicker delivery of projects in contracts, thereby ensuring that the contractor will adopt the latest technologies to execute the task. In this process, the contractor involves several specialized contractors to perform the specific functions (Shelbourn et al., 2007).

In addition, the construction industry's landscape is changing rapidly with frequent changes in technology and the complexity of the project itself. This new landscape matrix of construction projects emphasizes partnering, joint ventures, Public-Private Partnerships, and strategic alliances (Rahman et al., 2014). On the contrary, the construction industry has always been characterized by uncertainty, suspicion, and adversarial attitudes for a long time (Wu et al., 2008). Therefore, collaboration amongst project participants increases the value and predictability of work, creates an enabling environment for innovation and technical development, and encourages continuous development. In this context, Roy et al. has pointed out several benefits of collaboration in construction project management, including stakeholder management (Akintan and Morledge, 2013; Rahman et al., 2014). 
Prevalent research in collaboration demonstrates that collaboration between customers and suppliers reduces the cost of controlling, decreases the probability of failure, and creates a potential for innovation and learning. In the long run, it creates a culture of trust and reliability (Dietrich et al., 2008). Eriksson and Nilsson (2008) have reasoned that partnering, a form of collaborative working, aims to increase cooperation and integration between project participants by building trust and commitment.

Since Egan's (John, 1998) and Latham's (Latham, 1994) works, a boost in research is observed in the area of construction collaboration (Hughes et al., 2012). This boost in research has diversified the understanding of the term 'collaboration' to different researchers. For example, Hibbert et al. (2008) described collaboration as "all forms of situation where different parties work together." In addition, some researchers have argued that partnering and alliancing are also some forms of collaboration (M. Bresnen and Marshall, 2000a; Wu et al., 2008). According to Hughes et al. (2012) often in literature, collaboration is referred to as an umbrella term for alliancing, joint ventures, networking, and partnering.

Among the several aspects of collaboration, two critical aspects are - psychological factors and project level enablers ( Wu et al., 2008; Chakkol et al., 2017; Panahifar et al., 2018; Deep et al., 2019). Psychological factors essentially denote a person as collaborative, whereas project-level enablers play a crucial role in enabling a collaborative working environment amongst the project participants. In this context, Shuwei et al. have identified a spectrum of collaborative working attributes and felt that these attributes are necessary to develop a basic understanding of collaborative working in the construction industry ( $\mathrm{Wu}$ et al., 2008). Similarly, a study has identified six important factors that will lead to a willingness to collaborate amongst the contractors (Panahifar et al., 2018). Moreover, another similar study has produced a list of aspects and developed a questionnaire to rank them to produce a definition of collaboration (Hughes et al., 2012). A study conducted by Hudnurkar et al. (2014) found 28 factors affecting collaboration in the supply chain by conducting a detailed literature review. Similarly, another group researcher has argued that real-time communication between all stakeholders is essential for achieving effective coordination and collaboration.

Earlier, Eriksson and Nilsson (2008) have presented a case study on construction collaboration. They studied the benefits of partnering in each stage of a construction project in a pharmaceutical plant in Sweden. Their key conclusion was that implementation of collaborative working requires a long-term perspective and continuous improvement. Additionally, Chan et al. (2003) reviewed partnering in general and tried to find out how partnering can help construction projects in Hong Kong. They found that improved communication and relationship are two significant benefits derived from partnering in a construction project.

However, literature does not have a robust methodology to execute a project collaboratively (Akintan and Morledge, 2013). As each construction project is unique, developing a standard set of rules to implement collaborative work is impossible. In addition, research papers do not provide an exhaustive list of enablers of collaboration, which leads to confusion amongst the stakeholders when they often try to collaborate. Therefore, in this research, a list of enablers discussed in the literature is prepared, along with their frequency of appearance in literature.

The project level enablers, along with their frequencies, are presented in Table 1. 
Table 1: Project level enablers of collaboration and their frequency of discussion

\begin{tabular}{|c|c|c|c|}
\hline $\begin{array}{l}\text { Sl } \\
\text { No }\end{array}$ & $\begin{array}{c}\text { Project Level } \\
\text { Enablers }\end{array}$ & Frequency & Studies that discussed the enablers \\
\hline 1 & $\begin{array}{l}\text { Commitment } \\
\text { Towards Work }\end{array}$ & 15 & $\begin{array}{l}\text { M. Bresnen and Marshall, 2000b; M. Bresnen and } \\
\text { Marshall, 2000a; Girard and Robin, 2006; Neeraj Jha and } \\
\text { Misra, 2007; Dietrich et al., 2008; Eriksson and Nilsson, } \\
\text { 2008; Löfgren and Eriksson, 2009; Eriksson, 2010; } \\
\text { Hughes et al., 2012; Akintan and Morledge, 2013; Abdirad } \\
\text { and Pishdad-Bozorgi, 2014; Rahman et al., 2014; } \\
\text { Hudnurkar et al., 2014; Chakkol et al., 2017; Deep et al., } \\
\text { 2019) }\end{array}$ \\
\hline 2 & Trust & 14 & $\begin{array}{l}\text { (M. Bresnen and Marshall, 2000a; Shelbourn et al., 2007; } \\
\text { Wu et al., 2008; Dietrich et al., 2008; Löfgren and } \\
\text { Eriksson, 2009; Eriksson, 2010; Hughes et al., 2012; } \\
\text { Akintan and Morledge, 2013; Abdirad and Pishdad- } \\
\text { Bozorgi, 2014; Rahman et al., 2014; Hudnurkar } \text { et al., } \\
\text { 2014; Panahifar et al., 2018; Deep et al., 2019; Hamzeh et } \\
\text { al., 2019) }\end{array}$ \\
\hline 3 & Communication & 13 & $\begin{array}{l}\text { (M. Bresnen and Marshall, 2000a; Girard and Robin, } 2006 \\
\text { Shelbourn et al., 2007; Shen et al., 2008; Wu et al., 2008; } \\
\text { Eriksson and Nilsson, 2008; Eriksson, 2010; Hughes et al., } \\
\text { 2012; Abdirad and Pishdad-Bozorgi, 2014; Rahman et al., } \\
\text { 2014; Chakkol et al., 2017; Deep et al., 2019; Hamzeh et } \\
\text { al., 2019) }\end{array}$ \\
\hline 4 & $\begin{array}{l}\text { Real-Time } \\
\text { Information } \\
\text { Sharing }\end{array}$ & 13 & $\begin{array}{l}\text { (M. Bresnen and Marshall, 2000a; Shelbourn et al., 2007; } \\
\text { Shen et al., 2008; Eriksson and Nilsson, 2008; Hunter and } \\
\text { Leahey, 2008; Ahuja et al., 2009; Hughes et al., 2012; } \\
\text { Akintan and Morledge, 2013; Abdirad and Pishdad- } \\
\text { Bozorgi, 2014; Rahman et al., 2014; Hudnurkar et al., } \\
\text { 2014; Panahifar et al., 2018; Hamzeh et al., 2019) }\end{array}$ \\
\hline 5 & Shared Vision & 10 & $\begin{array}{l}\text { (M. Bresnen and Marshall, 2000a; Shelbourn et al., 2007; } \\
\text { Dietrich et al., 2008; Hunter and Leahey, 2008; Ahuja et } \\
\text { al., 2009; Löfgren and Eriksson, 2009; Hughes et al., } \\
\text { 2012; Rico, 2015; Chakkol et al., 2017; Deep et al., 2019) }\end{array}$ \\
\hline 6 & $\begin{array}{l}\text { Readiness to } \\
\text { Share } \\
\text { Information }\end{array}$ & 10 & $\begin{array}{l}\text { (M. Bresnen and Marshall, 2000b; Girard and Robin, } \\
\text { 2006; Neeraj Jha and Misra, 2007; Eriksson and Nilsson, } \\
\text { 2008; Shen et al., 2008; Wu et al., 2008; Ahuja et al., } \\
\text { 2009; Hudnurkar et al., 2014; Panahifar et al., 2018; } \\
\text { Hamzeh et al., 2019) }\end{array}$ \\
\hline 7 & $\begin{array}{l}\text { Adaption of } \\
\text { Information } \\
\text { Technology }\end{array}$ & 9 & $\begin{array}{l}\text { (Girard and Robin, 2006; Eriksson and Nilsson, 2008; } \\
\text { Hunter and Leahey, 2008; Ahuja et al., 2009; Eriksson, } \\
\text { 2010; Abdirad and Pishdad-Bozorgi, 2014; Hudnurkar et } \\
\text { al., 2014; Deep et al., 2019; Hamzeh et al., 2019) }\end{array}$ \\
\hline 8 & Process Design & 7 & (Hughes et al., 2012; Hamzeh et al., 2019) \\
\hline 9 & $\begin{array}{l}\text { Engagement of } \\
\text { Stakeholders }\end{array}$ & 6 & $\begin{array}{l}\text { (M. Bresnen and Marshall, 2000b; Neeraj Jha and Misra, } \\
\text { 2007; Shelbourn et al., 2007; Dietrich et al., 2008; } \\
\text { Chakkol et al., 2017; Hamzeh et al., 2019) }\end{array}$ \\
\hline 10 & Reliability & 5 & $\begin{array}{l}\text { (Dietrich et al., 2008; Eriksson, 2010; Hudnurkar et al., } \\
\text { 2014; Chakkol et al., 2017; Deep et al., 2019) }\end{array}$ \\
\hline
\end{tabular}


These ten enablers are sorted based on the frequencies of discussion, and in this study, all ten enablers are used. In addition, it has been observed that 'commitment towards work,' 'trust,' and 'communication' are discussed the most in prevalent literature.

Similarly, psychological factors are presented in Table 2.

Table 2: Psychological factors of collaboration and their frequency of discussion

\begin{tabular}{|c|c|c|c|}
\hline $\begin{array}{r}\text { Sl } \\
\text { No }\end{array}$ & $\begin{array}{c}\text { Psychological } \\
\text { Factors }\end{array}$ & Frequency & Studies that discussed the enablers \\
\hline 1 & $\begin{array}{l}\text { Building } \\
\text { Relationships }\end{array}$ & 10 & $\begin{array}{l}\text { (M. Bresnen and Marshall, 2000b; Shelbourn et al., 2007; } \\
\text { Wu et al., 2008; Löfgren and Eriksson, 2009; Eriksson, } \\
\text { 2010; Hughes et al., 2012; Rahman et al., 2014; Rico, } \\
\text { 2015; Chakkol et al., 2017; Hamzeh et al., 2019) }\end{array}$ \\
\hline 2 & $\begin{array}{l}\text { Self- } \\
\text { Motivation }\end{array}$ & 8 & $\begin{array}{l}\text { (M. Bresnen and Marshall, 2000b; M. Bresnen and } \\
\text { Marshall, 2000a; Shelbourn et al., 2007; Dietrich et al., } \\
\text { 2008; Wu et al., 2008; Hughes et al., 2012; Rahman et al., } \\
\text { 2014; Rico, 2015) }\end{array}$ \\
\hline 3 & Transparency & 6 & $\begin{array}{l}\text { (Eriksson, 2010; Hughes et al., 2012; Hudnurkar et al., } \\
\text { 2014; Chakkol et al., 2017; Panahifar et al., 2018; Hamzeh } \\
\text { et al., 2019) }\end{array}$ \\
\hline 4 & $\begin{array}{l}\text { Being } \\
\text { Respectful }\end{array}$ & 6 & $\begin{array}{l}\text { (Girard and Robin, 2006; Shelbourn et al., 2007; Wu et al., } \\
\text { 2008; Hughes et al., 2012; Chakkol et al., 2017; Hamzeh et } \\
\text { al., 2019) }\end{array}$ \\
\hline 5 & $\begin{array}{l}\text { Being } \\
\text { Appreciative }\end{array}$ & 2 & (M. Bresnen and Marshall, 2000a; Girard and Robin, 2006) \\
\hline 6 & Discipline & 2 & (Neeraj Jha and Misra, 2007; Eriksson, 2010) \\
\hline 7 & Curiosity & 2 & (Rico, 2015; Chakkol et al., 2017) \\
\hline 8 & Generosity & 1 & $($ Rico, 2015) \\
\hline
\end{tabular}

From Table 2, we see that 'building relationships' is discussed the most in literature followed by 'self-motivation'. Further, prevailing literature does not have any intuitive framework to measure the collaboration in a construction project. This research has identified these gaps, and a framework to measure the level of collaboration in construction is developed. The following section presents the methodology used to create this framework.

\section{METHODOLOGY}

The methodology used for this research is presented in Figure 1. Both inductive and deductive research approaches were used in this research. First, a basic literature review was done, as illustrated in the previous section. In addition, to understand the current practices in the Indian construction industry, a round comprising of four unstructured interviews was conducted with richly experienced construction professionals of India.

The data collected were analyzed conceptually, and based on the gaps found, the problem statement was defined. In addition, the workflow of a conceptual framework was also developed. Finally, the input requirements for the conceptual framework were quantified to measure the extent of collaboration in a construction project. 


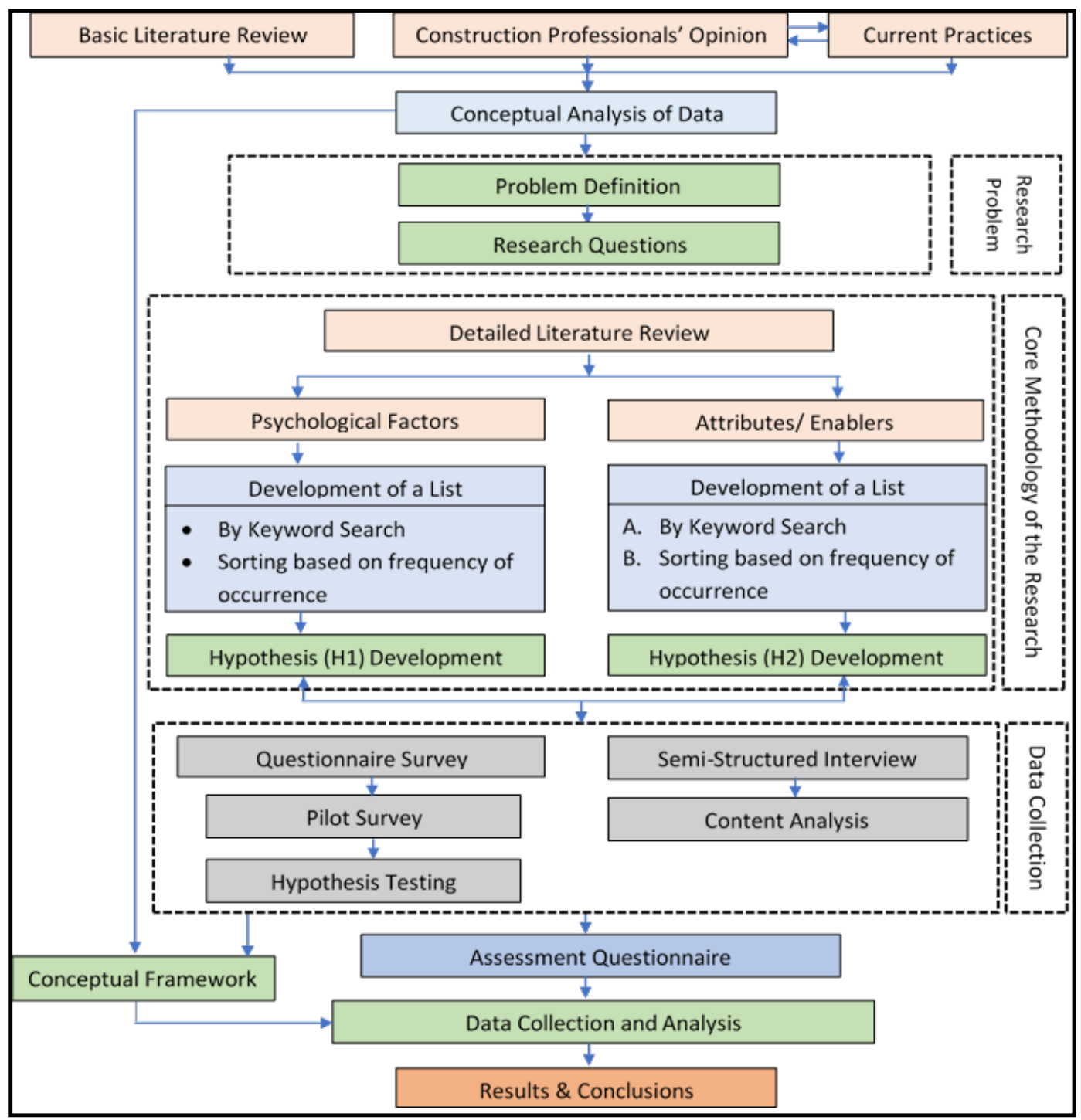

Figure 1: Research methodology for the present study

A keyword search was conducted on the existing literature published on construction collaboration. The keywords used were 'collaboration in construction,' 'interface management,' 'measurement of collaboration,' and 'aspect of collaboration.' In addition, a list of project-level enablers and psychological factors was made after selecting the relevant literature from the keyword search. Based on Tables 1 and 2, two hypotheses were developed as inductive theories. These are presented below:

Hypothesis 1 (H1): A person is said to be collaborative if they express the following psychological features through their work in a construction project setting.

The psychological factors are: Curiosity, Generosity, Appreciative, Building relationships, Transparency, Discipline, Self-motivation, Respectfulness.

Hypothesis 2 (H2): A particular project's hierarchy is collaborative if the person/teams responsible for the assigned work at that level show experience or perform with the following enablers at the place. 
These project-level enablers of collaboration are: Trust, Good communication, Shared vision, Process design, Engagement of stakeholders, Adoption of information technology, Real-time information sharing, Reliability on work assigned, Commitment towards work, Readiness to share information.

It can be noted that the project level enablers in Table 1 and psychological factors in Table 2 were from different research papers across several countries. This conceptual framework was explicitly intended to be used for Indian construction projects; therefore, understanding the relevance of these enablers in the Indian context was required. Thus, to capture the perspective of construction professionals across India, a detailed and specific questionnaire was designed. The questionnaire aimed to sort the most critical enablers for the Indian construction industry by collecting data from construction professionals. The data were intended to be collected in a five pointer Likert scale - 1 denoting 'Not Important' to 5 denoting 'Very Important'.

A pilot survey was done to ensure that the questions were understood clearly and there was no ambiguity in word selection. Next, the questionnaire was shared with experienced construction professionals across various projects and companies. They were requested to follow the instructions while answering the questionnaire and respond based on their understanding of construction management.

An appropriate statistical hypothesis testing model that includes 't-test' and 'MannWhitney Rank Sum test' was proposed, and the data collected using the questionnaire was statistically analyzed. The statistical hypothesis testing model resulted in developing the 'stakeholder- project level enablers' matrix. In the deductive research approach of this study, this 'stakeholder- project level enabler' matrix was the basis for the conceptual framework.

In the next section, the results of the questionnaire survey are presented. The results were used to derive the conceptual framework.

\section{RESULTS AND FRAMEWORK DERIVATION}

The questionnaire was sent to 130 participants, and 74 responses were received. This yielded an adequate response rate of $56.92 \%$.

Figure 2 represents the demographics of the respondents. Figure 2(a) shows respondents' affiliation concerning Client, Project Management Consultants, Designers, Main Contractors, and Subcontractors. It can be observed that $64 \%$ of the respondents are main contractors. Similarly, the experience of the respondents is shown in Figure 2(b). It is observed that $73 \%$ of the respondents have work experience between $2-12$ years.

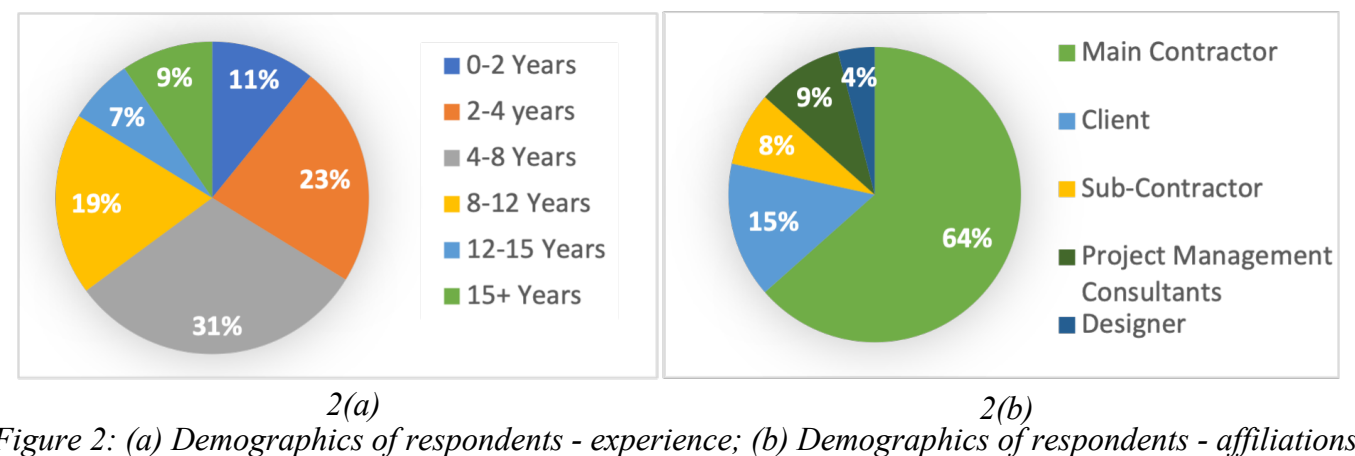


Table 3: Results of statistical hypothesis testing

\begin{tabular}{|c|c|c|c|c|c|c|}
\hline $\begin{array}{l}\text { Sl. } \\
\text { No }\end{array}$ & Psychological Factors & $\begin{array}{l}\text { Main } \\
\text { Cont. }\end{array}$ & Client & PMC & $\begin{array}{c}\text { Sub- } \\
\text { Contractor }\end{array}$ & Designer \\
\hline 1 & Curiosity & $\mathrm{X}$ & $X$ & $\mathrm{X}$ & $\mathrm{X}$ & $\mathrm{X}$ \\
\hline 2 & Generosity & $\Delta$ & $\boldsymbol{\Delta}$ & $\Delta$ & $\Delta$ & $\boldsymbol{\Delta}$ \\
\hline 3 & Being Appreciative & $\Delta$ & $\boldsymbol{\Delta}$ & $\Delta$ & $\Delta$ & $\Delta$ \\
\hline 4 & Building Relationships & $\mathrm{X}$ & $\mathrm{X}$ & $\mathrm{X}$ & $\mathrm{X}$ & $\mathrm{X}$ \\
\hline 5 & Transparency & $\Delta$ & $\boldsymbol{\Delta}$ & $\boldsymbol{\Delta}$ & $\Delta$ & $\boldsymbol{\Delta}$ \\
\hline 6 & Discipline & $\mathrm{X}$ & $\mathrm{X}$ & $\mathrm{X}$ & $X$ & $X$ \\
\hline 7 & Self-Motivation & $\mathrm{X}$ & $\mathrm{X}$ & $\mathrm{X}$ & $\mathrm{X}$ & $\mathrm{X}$ \\
\hline 8 & Being Respectful & $\mathrm{X}$ & $\mathrm{X}$ & $\mathrm{X}$ & $\mathrm{X}$ & $\mathrm{X}$ \\
\hline \multicolumn{7}{|c|}{ Project Level Enablers } \\
\hline 9 & Good Communication & $\boldsymbol{\Delta}$ & $\boldsymbol{\Delta}$ & $\Delta$ & $\Delta$ & $\boldsymbol{\Delta}$ \\
\hline 10 & Trust & $\mathrm{X}$ & $\mathrm{X}$ & $\mathrm{X}$ & $\mathrm{X}$ & $\mathrm{X}$ \\
\hline 11 & Shared Vision & $\mathrm{X}$ & $\mathrm{X}$ & $\mathrm{X}$ & $\mathrm{X}$ & $\mathrm{X}$ \\
\hline 12 & Process Design & $\Delta$ & $\Delta$ & $\Delta$ & $\Delta$ & $\Delta$ \\
\hline 13 & Engagement of Stakeholders & $\Delta$ & $\boldsymbol{\Delta}$ & $\Delta$ & $\Delta$ & $\Delta$ \\
\hline 14 & $\begin{array}{l}\text { Adoption of Information } \\
\text { Technology }\end{array}$ & $\boldsymbol{\Delta}$ & $\boldsymbol{\Delta}$ & $\Delta$ & $\Delta$ & $\Delta$ \\
\hline 15 & Real-Time Information Sharing & $\boldsymbol{\Delta}$ & $\boldsymbol{\Delta}$ & $\boldsymbol{\Delta}$ & $\boldsymbol{\Delta}$ & $\boldsymbol{\Delta}$ \\
\hline 16 & Reliability of Work & $\Delta$ & $\boldsymbol{\Delta}$ & $\Delta$ & $\Delta$ & $\Delta$ \\
\hline 17 & Commitment Towards Work & $\mathrm{X}$ & $\mathrm{X}$ & $\mathrm{X}$ & $\mathrm{X}$ & $\mathrm{X}$ \\
\hline 18 & Readiness to Share Information & $\mathrm{X}$ & $\mathrm{X}$ & $\mathrm{X}$ & $\mathrm{X}$ & $\mathrm{X}$ \\
\hline
\end{tabular}

As per the responses obtained from main contractors, it is observed that "generosity," "being appreciative," and "transparency" are three crucial intrapersonal psychological factors for collaboration.

Similarly, "good communication," "process design," "engagement of stakeholders," "adoption of information technology," "real-time information sharing," "reliability towards work" are project-level enablers, which are essential for defining a project as a collaborative project.

In addition, no significant difference is observed in the pattern of responses of the main contractors and other stakeholders within the scope of this research. This statement was derived after testing the data using Mann-Whitney Rank Sum Test. Therefore, the conclusion drawn in the previous paragraph about main contractors will hold for other stakeholders, viz. clients, project management consultants, subcontractors, and designers.

The conceptual framework for measuring the collaboration in a construction project was derived and is presented in Figure 3. The results of hypotheses testing presented in Table 3 are the primary input data for this conceptual framework. From Table 1, a list of ten enablers along with their frequency was obtained. The results of the hypothesis testing methodology yielded the six most important enablers of collaboration of the Indian 
construction industry. The psychological factors are not used in the conceptual framework.

For each of these six project level enablers, a set of statements were derived so that these statements together define each of the project level enablers. These statements were developed intuitively and based on the authors' understanding, supplemented by the literature review. These statements are to be used for measuring collaboration in a construction project.

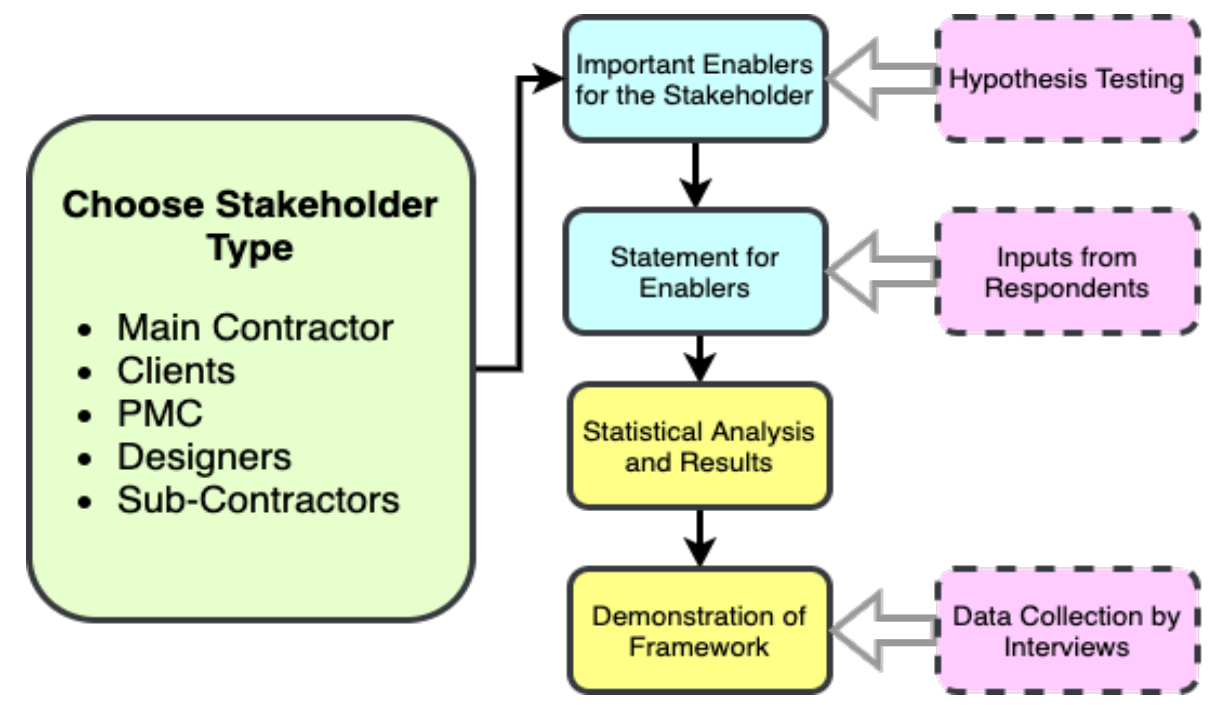

Figure 3: Conceptual framework to measure the level of collaboration in a construction project

The statements are assessed by the project participants of a construction project in a 5point Likert scale. The average score of the statements under each project level enabler is taken and overall Likert score is the algebraic sum of all project level enablers.

The level of collaboration of a construction project is defined into three categories'collaboration visible to great extent,' 'collaboration visible to some extent,' and 'no visible collaboration.' This classification is based on the overall Likert scale value of the six sorted project level enablers of collaboration, which is presented in Table 4. The overall Likert score (Column 3, Table 4) is calculated from the inputs collected from the construction professionals of the project.

Table 4: Basis of measuring the level of collaboration based on Likert scale

\begin{tabular}{llc}
\hline SI No & \multicolumn{1}{c}{ Collaboration Extent or Level of Collaboration } & Overall Likert Score \\
\hline 1 & Collaboration Visible to Great Extent & $30-21$ \\
2 & Collaboration Visible to Some Extent & $15-21$ \\
3 & No Visible Collaboration & $<15$ \\
\hline
\end{tabular}

\section{DISCUSSION}

Hypotheses testing resulted that three out of the eight psychological factors are important for defining a person as a natural collaborator. These are "generosity," "being appreciative," and "transparency." In addition, six out of ten project-level enablers are important for defining project-level collaboration. These are "good communication," 
"process design," "engagement of stakeholders," "adoption of information technology," "real-time information sharing," and "reliability towards work." Hence, by identifying these aspects, the first objective of the study was achieved.

These findings can be related to the project management practices in the Indian construction industry. Construction projects involving multiple stakeholders should have a system enabling and promoting collaborative activities within construction projects. It is synonymous with process design, engagement of stakeholders, and adoption of information technology to facilitate collaboration. In addition, construction projects often face problems due to a lack of friendliness and readiness to share information. This argument supports the findings that good communication and willingness to share information enhances collaboration within construction projects.

In line with the findings of this study, existing literature has also discussed many aspects for successful collaboration within construction projects. For example, researchers have illustrated the importance of good communication as an enabler of collaboration (Eriksson, 2010; Panahifar et al., 2018). Further, readiness to share information is also denoted as a key enabler of collaboration Hughes et al., 2012). Moreover, management should ensure its role in embracing and enhancing a culture of collaboration in construction projects and enabling it. In this context, the participants should have a shared vision, and the construction activities are to be designed accordingly (Wu et al., 2008; Narayanan et al., 2019).

In addition, the adoption of information technology such as BIM can provide a platform for all project participants to collaborate effectively ( $\mathrm{Wu}$ et al., 2008; Hughes et al., 2012). The BIM integration in project management requires all the stakeholders to participate in the collaboration process.

However, literature does not have an explicit framework to measure the collaboration of construction projects that includes the soft issues of collaboration. Therefore, in this research, a framework is developed using the key soft issues for the construction industry to measure collaboration in a construction project. This adds value to the existing literature on construction collaboration.

However, many researchers have argued the importance of trust as a project-level enabler of collaboration. On the contrary, the hypothesis testing results from this study contradicted these arguments. It was unexpected to note that trust is not important as per the hypotheses testing methodology. Similar observations were recorded for commitment towards work.

Future work may include validating the collaboration measurement framework by performing few case studies to continue this research. In this process, the construction professionals will understand the importance of collaboration and get acquainted with the concepts of collaboration. Furthermore, this value addition to the conceptual framework can be enhanced by incorporating the feedback received from the construction professionals.

\section{CONCLUSIONS}

The research presented in this paper tries to find the key psychological factors and project enablers of collaboration for a construction project. The key contribution of this paper is two-folded. Firstly, a list of psychological factors and project enablers are developed from 
the literature obtained from a keyword search on construction collaboration. Appropriate hypotheses testing methodology is used to sort the important psychological factors and project level enablers for the Indian construction industry. This resulted in three psychological factors and six project enablers amongst the sorted, which are important for the Indian construction industry. Secondly, a conceptual framework is derived that includes these six project enablers to measure the collaboration of a construction project. However, the psychological factors were not used in the conceptual framework.

The findings of the hypothesis testing methodology are in line with the discussions presented in the existing literature. However, this research adds value to the current literature as it develops a framework to measure collaboration in a construction project. The future scope of this research may be to develop a methodology to validate the framework and perform some case studies.

\section{REFERENCES}

Abdirad, H. and Pishdad-Bozorgi, P. 2014. Developing a Framework of Metrics to Assess Collaboration in Integrated Project Delivery, 50 ${ }^{\text {th }}$ Annual International Conference Proceedings, (March), pp. 1-9.

Ahuja, V., Yang, J. and Shankar, R. 2009. Study of ICT adoption for building project management in the Indian construction industry, Automation in Construction, 18(4), pp. 415-423.

Akintan, O. A. and Morledge, R. 2013. Improving the Collaboration between Main Contractors and Subcontractors within Traditional Construction Procurement, Journal of Construction Engineering, 2013, pp. 1-11.

Bresnen, M. and Marshall, N. 2000. Building partnerships: Case studies of client-contractor collaboration in the UK construction industry, Construction Management and Economics, 18(7), pp. 819-832.

Bresnen, M. and Marshall, N. 2000. Partnering in construction: A critical review of issues, problems and dilemmas, Construction Management and Economics, 18(2), pp. 229-237.

Chakkol, M., Finne, M. and Johnson, M. 2017. Understanding the psychology of collaboration: What makes an effective collaborator?, (March), pp. 2-31.

Deep, S., Gajendran, T. and Jefferies, M. 2019. A systematic review of "enablers of collaboration" among the participants in construction projects, International Journal of Construction Management, pp. 1-13.

Dietrich, P., Eskerod, P., Dalcher, D. and Sandhawalia, B. 2008. The Dynamics of Collaboration in Multipartner Projects, Project Management Journal, 39(4), pp. 28-42.

Eriksson, P. E. 2010. Improving construction supply chain collaboration and performance: A lean construction pilot project, Supply Chain Management, 15(5), pp. 394-403.

Eriksson, P. E. and Nilsson, T. 2008. Partnering the Construction of a Swedish Pharmaceutical Plant: Case Study, Journal of Management in Engineering, 24(4), pp. 227-233.

Girard, P. and Robin, V. 2006. Analysis of collaboration for project design management, Computers in Industry, 57(8-9), pp. 817-826.

Hamzeh, F., Rached, F., Hraoui, Y., Karam, A. J. and Malaeb, Z. 2019. Integrated project delivery as an enabler for collaboration: a Middle East perspective, Built Environment Project and Asset Management, 9(3), pp. 334-347.

Hudnurkar, M., Jakhar, S. and Rathod, U. 2014. Factors Affecting Collaboration in Supply Chain: A Literature Review, Procedia - Social and Behavioral Sciences, 133, pp. 189-202.

Hughes, D., Williams, T. and Ren, Z. 2012. Differing perspectives on collaboration in construction, Construction Innovation, 12(3), pp. 355-368.

Hunter, L. and Leahey, E. 2008. Collaborative Research in Sociology: Trends and Contributing Factors, The American Sociologist, 39(4), pp. 290-306.

John, E. 1998. Rethinking construction, The report of the construction task force. Available from: https://constructingexcellence.org.uk/wp-content/uploads/2014/10/rethinking_construction_report.pdf. [Accessed 25 ${ }^{\text {th }}$ March 2021] 
Latham, M. (1994) Constructing the Team, The Final Report of the Government/Industrial Review of Procurement and Contractual Arrangements in the UK Construction Industry. Available from: https://constructingexcellence.org.uk/wp-content/uploads/2014/10/Constructing-the-team-TheLatham-Report.pdf. [Accessed $2^{\text {nd }}$ March 2021]

Löfgren, P. and Eriksson, P. E. 2009. Effects of collaboration in projects on construction project performance, Association of Researchers in Construction Management, ARCOM 2009 - Proceedings of the 25th Annual Conference, 2, pp. 595-604.

Narayanan, S., Kure, A. M. and Palaniappan, S. 2019. Study on Time and Cost Overruns in Mega Infrastructure Projects in India, Journal of The Institution of Engineers (India): Series A, 100(1), pp. 139-145.

Neeraj Jha, K. and Misra, S. 2007. Ranking and classification of construction coordination activities in Indian projects, Construction Management and Economics, 25(4), pp. 409-421.

Panahifar, F., Byrne, P.J. and Heavey, C. 2018. Supply chain collaboration and firm's performance, Journal of Enterprise Information Management, 31(3), pp. 358-379.

Rahman, S. H. A., Endut, I. R., Faisol, N. and Paydar, S. 2014. The Importance of Collaboration in Construction Industry from Contractors' Perspectives, Procedia-Social and Behavioral Sciences, 129, pp. 414-421.

Rico, D. F. 2015. The 12 Attributes of Successful Collaboration Between Highly-Creative People. Available at: www.davidfrico.com/collaboration-attributes.pdf.[Accessed $1^{\text {st }}$ November 2020]

Shelbourn, M., Bouchlaghem, N. M., Anumba, C. and Carrillo, P. 2007. Planning and implementation of effective collaboration in construction projects, Construction Innovation, 7(4), pp. 357-377.

Shen, W., Hao, Q., Mak, H., Neelamkavil, J., Xie, H. and Dickinson, J. 2008. Systems integration and collaboration in construction: A review, Proceedings of the $200812^{\text {th }}$ International Conference on Computer Supported Cooperative Work in Design, CSCWD, 1(May), pp. 11-22.

Wang, B. Y. 2000. Coordination Issues in Chinese Large Building Projects, 16(December), pp. 54-61.

Wu, S., Greenwood, D. and Steel, G. 2008. Exploring the Attributes of Collaborative Working in Construction Industry, Northumbria Built and Virtual Environment Working Paper Series, 1(2), pp. 135-147. 